\title{
URBAN DIPLOMACY: COLOGNE, THE RHENISH LEAGUE (1254-1257) AND THE RHENISH URBAN LEAGUE (1381-1389)
}

\author{
Joseph P. Huffman \\ Messiah College
}

\section{RESUMEN}

Una de las particularidades de las ciudades de Renania durante la Edad Media fue su propensión a formar ligas (Städtebünde) por iniciativa propia, en ausencia de una autoridad central fuerte imperial. Dichas alianzas significaban notables colaboraciones diplomáticas entre rivales económicos con el fin de resolver conflictos y mantener la "paz del rey" (Landfriede) cuando el monarca era incapaz de hacerlo. La inclusión de esas ligas urbanas regionales e interregionales ha comenzado recientemente en la historiografía de lengua alemana sobre la historia urbana europea, pero su ausencia sigue siendo profunda en la de lengua inglesa y otras historiografías occidentales. Este artículo trata de paliar dicha ausencia historiográfica. Tras ubicar el tema en su contexto historiográfico moderno, se estudian las dos grandes ligas urbanas renanas (1245-1247 y 1381-1389), proporcionando un marco más amplio para una consideración más atenta de la alianza urbana renana liderada por Colonia en 1301-1320, dirigida contra los arzobispos y electores del príncipe de Colonia, Maguncia y Tréveris. La sofisticación de las colaboraciones administrativas, financieras, diplomáticas, militares y comunicativas entre las ciudades renanas en este período es extraordinaria y merece ser incluida en el relato de la resolución de conflictos, la cultura política y el gobierno territorial de la Europa bajomedieval.

Palabras clave: Alemania; Renania; Colonia; Historia urbana; Historiografía; Diplomacia medieval. 


\begin{abstract}
One of the distinctives of Rhineland cities of the central and later Middle Ages is their propensity to form leagues (Städtebünde) on their own initiative in the absence of strong imperial central authority. These alliances represent remarkable diplomatic collaborations between otherwise economic rivals in order to resolve conflicts and sustain the "king's peace" (Landfriede) when the monarch was incapable of doing so. The inclusion of these regional and interregional Rhenish urban leagues into the historiography of European urban history has only recently begun in German-language medieval scholarship, yet it remains profound in its absence among Anglophone or any other western historiography on medieval urban history. This article seeks to address such an historiographical absence by introducing the subject within the context of this volume's comparative, European-wide focus on medieval institutional structures, conflicts, and political culture. After situating the subject in its modern historiographical context, the two great Rhenish urban leagues (1254-1257 and 1381-1389) are studied, providing a further framing context for a close consideration of the Cologneled Rhineland urban alliance of 1301-1320 directed against the electorprince archbishops of Cologne, Mainz, and Trier. The sophistication of administrative, diplomatic, financial, military, and communication organs among the Rhenish cities in this period is extraordinary and thus provides additional insight into central and later medieval European political culture, conflict resolution, and territorial government. Medieval urban history thereby extends its landscape from that within the city walls to the pathways of diplomatic discourse between them.
\end{abstract}

Keywords: Germany, Rhineland, Cologne, Urban History, Historiography, Medieval Diplomacy.

There is perhaps no more powerful and lasting image of the medieval city than its defensive walls. From municipal seals to modern monographs, cities and towns often appear as anachronistic islands in a sea of feudal jurisdictions, isolated immunities experimenting with forms of selfgovernance and commercial activity. Yet medieval German towns and cities actively formed networks of solidarity and mutual aid, even as early as the thirteenth century. Unfortunately, the slim nineteenth-century Germanlanguage historiography on this activity was written by nationalist-liberal academics who framed such networking as a quintessential bourgeois battle for national unity against the fragmenting forces of aristocracy and the 
Catholic Church. Constitutional and legal scholars of the twentieth century produced an only slightly larger body of scholarship that characterized these alliances as vehicles for legal reform and juridical legitimation of bourgeois society, while Marxist historians saw them as the locus of social conflict between the forces of the bourgeoisie and feudalism. So in fact it is only in the past decade or so that German-language urban historians have studied these alliances and produced a more nuanced understanding of their functions within an urban landscape of networks. ${ }^{1}$ The recent completion of a long-term editing project on documents related to the Rhineland alliances has also provided a welcome impetus for deeper investigations into the inner workings of these urban coalitions. ${ }^{2}$

Perusal of non-German historiography on medieval German cities indicates that, apart from the Hanseatic League, the integration of medieval German urban alliances into wider European urban history has only just begun, though this literature leaves the impression that such urban alliances began only at the close of the medieval period. ${ }^{3}$ As capacious an observer as Susan Reynolds

$1 \quad$ KIE $\beta$ LING, ROLF, «Städtebünde und Städtelandschaften im oberdeutschen Raum: Ostschwaben und Altbayern im Vergleich», in ESCHER, MONIKA, ALFRED HAVERKAMP and FRANK G. HIRSCHMANN, Städtelandschaft - Städtenetz zentralörtliches Gefüge. Ansätze und Befunde zur Geschichte der Städte im hohen und späten Mittelalter, Trier 2000, pp. 79-116; DILCHER, GERHARD, «Mittelalterliche Stadtkommune, Städtebünde und Staatsbildung. Ein Vergleich OberitalienDeutschland», in LÜCK, HEINER AND BERND SCHILDT, Recht - Idee - Geschichte. Beiträge zur Rechts- und Ideengeschichte für Rolf Lieberwirth anläßlich seines 80. Geburtstages, Cologne, Weimar, Vienna, 2000, pp. 453-467; HOLGER, TH. GRÄF VON and KATRIN KELLER, Städtelandschaft - Réseau urbain - Urban Network. Städte im regionalen Kontext in Spätmittelalter und Früher Neuzeit, Cologne, Weimar, and Vienna, 2004; KREUTZ, BERNHARD, Städtebünde und Städtenetz am Mittelrhein im 13. und 14. Jahrhundert, Trier 2005; BÖNNEN, GEROLD, «Der Rheinische Bund von 1254/56: Voraussetzungen, Wirkungsweise, Nachleben», in: FELTEN, FRANZ J., Städtebünde - Städtetage im Wandel der Geschichte, Stuttgart 2006, pp. 13-35; DISTLER, EVAMARIE, Städtebünde im deutschen Spätmittelalter. Eine rechtshistorische Untersuchung zu Begriff, Verfassung und Funktion, Studien zur europäischen Rechtsgeschichte 207, Frankfurt am Main, 2006; THON, ALEXANDER, «Städte gegen Burgen. Tatsächliche und mutmaßliche Belagerungen von Burgen am Mittelrhein durch den Rheinischen Bund 1254-1257» Jahrbuch für westdeutsche Landesgeschichte 34 (2008), pp. 17-42.

2 RUSER, KONRAD, Die Urkunden und Akten der oberdeutschen Städtebünde vom 13. Jahrhundert bis 1549, Göttingen 1979-2005, 3 vols. For historiographical surveys of this field of research see KREUTZ, Städtebünde und Städtenetz am Mittelrhein im 13. und 14. Jahrhundert, pp. 18-30 and DISTLER, Städtebünde im deutschen Mittelalter, pp. 15-36. DISTLER also provides a complete bibliography of all published Germanlanguage scholarship on the subject of the urban leagues of the central and later Middle Ages.

3 BUCHHOLZER-RÉMY, LAURENCE, Une ville en ses réseaux: Nuremberg à la fin $d u$ Moyen Âge, Paris, 2006, BUCHHOLZER-RÉMY, LAURENCE and OLIVIER RICHARD, 
only mentioned pre-Hanseatic urban leagues in passing as mere precursors of the Hansa, though the two urban movements do not share the same pedigree -- neither in organization, purpose, nor outcomes. ${ }^{4}$ The traditional emphasis on urban development of burgher autonomy, legal status, administrative and commercial skill, self-government and civic life during the central and later Middle Ages within the city walls has ironically obscured our awareness that these developments also functioned collectively beyond and between those walls. And once we add the dimension of inter-city collaboration, the central and later medieval history of cities and towns begins to share some of the contours of centralized governance, state-like administrative organs, and diplomacy once thought to be the preserve of territorial lords and monarchs. Networks of extra-territorial solidarity and mutual aid were not the sole domain of the aristocracy, nor was the development of a political culture of diplomacy, communication, fiscal planning, and military organization. German urban polities were also developing these aspects of their own socioeconomic, political, and cultural history during the central and later Middle Ages. Thus any study of medieval German institutional structures and political culture is incomplete without the inclusion of these regional and trans-regional urban alliance networks. Such integration is just beginning to take place in Germanophone historiography, but medieval Rhineland urban alliance networks still remain virtually unknown in other national historiographies. ${ }^{5}$

Though central and later medieval German cities achieved significant jurisdictional and economic immunities for their citizens within the confines

eds. Ligues urbaines et espace à la fin du Moyen Âge - Städtebünde und Raum in Spätmittelalter, Strasbourg, 2012, and FORSÉN, BJÖRN, «Was there a south-west German city-state culture?», in HANSEN, MOGENS HERMAN, A comparative study of six city-state cultures: an investigation, Viborg, 2002, pp. 91-106. The urban alliances of medieval Germany are nowhere to be found in such standard Anglophone surveys of medieval urban history as NICHOLS, DAVID, Urban Europe, 1100-1700, New York, 2003 and LILLEY, KEITH D., Urban life in the Middle Ages 1000-1450, New York, 2002.

4 REYNOLDS, SUSAN, Kingdoms and communities in Western Europe 900-1300, 2nd ed., Oxford, 1997, p. 175. German scholars include the Hanseatic League in general overviews of various types urban collaboration, (see SCHMIEDER, FELICITAS, Die mittelalterlicher Stadt, 2nd edition, Darmstadt, 2009, pp. 138-139; HIRSCHMAN, Frank G., Die Stadt im Mittelalter, Munich 2009, pp.40-41), while scholars of the Rhenish and Swabian leagues rightly treat it as a special exception given its overwhelmingly commercial nature (See DISTLER, Städtebünde im deutschen Spätmittelalter, pp. 53-68).

5 WATTS, JOHN, The making of polities: Europe 1300-1500, Cambridge, 2009, pp. 101105 does mention the German urban alliances in his discussion of European communes and sworn associations. 
of the city walls, conversely they had limited power to control the wider environment beyond the walls on behalf of these citizens. This was especially so given the aristocratic and princely territorial lordships (Fürstenstaaten) being consolidated in the Rhineland region in the later Middle Ages. The citizens of Cologne, for example, had achieved autonomy by driving their archbishop permanently from the city at the Battle of Worringen in $1288,{ }^{6}$ yet the city itself was still geographically enveloped by the archbishop's territorial principality (Kurfürstentum Köln or Kurköln) and he was only as far away as his palaces in Bonn and Brühl. In essence, all medieval German cities faced the same obvious problem: while their citizens were increasingly mobile they themselves were immobile organizations by nature, which required creative strategies to provide security for their people, goods, and capital when in transit. Since all urban magistrates dealt with this same problem, solidarity between them quickly proved to be a common good. ${ }^{7}$ And thus urban alliance networks emerged in Germany from the early thirteenth century. Our focus here shall be on the Rhineland cities and particularly on Cologne, though significant and long-lived urban leagues emerged as well in Swabia and the Alsace, ${ }^{8}$ the Lake Constance region, ${ }^{9}$

6 SCHÄFKE, WERNER, Worringen 1288. Historische Entscheidung im europäischen Nordwesten, Cologne, 1988; SCHÄFKE, WERNER, Der Name der Freiheit 12881988. Aspekte Kölner Geschichte von Worringen bis heute, Cologne, 1988; JANNSEN, WILHEM and HUGO STEHKÄMPER, Der Tag bei Worringen, 5. June 1288, Cologne and Vienna, 1988; TORUNSKY, VERA, Worringen 1288: Ursachen und Folgen einer Schlacht, Cologne, 1988.

7 GROTEN, MANFRED, Die deutsche Stadt im Mittelalter, Stuttgart, 2013, p. 170.

8 SCHULER, PETER-JOHANNES, «Die Rolle der schwäbischen und elsässischen Städtebünde in den Auseinandersetzungen zwischen Ludwig dem Bayern und Karl IV.», Blätter für deutsche Landesgeschichte 114 (1978), pp. 659-694; VOGLER, B., «Die Elsässische Dekapolis (1354-1679)»," in KIRCHGÄSSNER, BENHARD, and HANSPETER BECHT, Vom Städtebund zum Zweckverband, Sigmaringen, 1994, pp. 21-28; SITTLER, LUCIEN, «Der elsässische Zehnstädtebund, seine geschichtliche Eigenheit und seine Organisation», Esslinger Studien 10 (1964), pp. 59-77; VISCHER, WILHELM, «Zur Geschichte des schwäbischen Städtebundes der Jahre 1376-1389», Forschungen zur deutschen Geschichte 2 (1862), pp. 1-202, and 3 (1863), pp. 1-39; BLEZINGER, HARRO, Der Schwäbische Städtebund in den Jahren 1438-1445 mit einem Überblick über seine Entwicklung seit 1389, Stuttgart, 1954; SCHILDHAUER, JOHANNES, «Der Swäbische Städtebund -- Ausdruck der Kraftentfaltung des deutschen Bürgertums in der zweiten Hälfte des 14. Jahrhunderts», Jahrbuch für Geschichte des Feudalismus 1 (1977) 187-210.

$9 \quad$ FÜCHTNER, JÖRG, Die Bündnisse der Bodenseestädte bis zum Jahre 1390: Ein Beitrag zur Geschichte des Einungswesens, der Landfriedenswahrung und der Rechtsstellung der Reichsstädte, Göttingen, 1970. 
Saxony, ${ }^{10}$ Wetterau (Hesse) ${ }^{11}$ Thuringia,${ }^{12}$ and Upper Lusatia. ${ }^{13}$

\section{THE RHENISH LEAGUE (RHEINISCHER BUND) 1254-1257}

Unlike the Italian city-states of the Lombard League, German cities like Cologne did not possess their own territorial state (contado), ${ }^{14}$ though several of the northwestern imperial and free cities associated with the Hanseatic League did purchase some villages and rural mortgage revenues in the surrounding countryside as investments. ${ }^{15}$ Nonetheless, describing any medieval German city as a city-state does not comport well with the German Empire's constitutional structure. ${ }^{16}$ Rather, with Cologne, Nuremberg, and Augsburg chief among them, the major German cities preferred to exercise influence over their respective hinterlands through commercial and manufacturing clout rather than to compete with local and regional

10 MENDTHAL, H., Die Städtebünde und Landfrieden in Westfalen bis zum Jahre 1371. Ein Beitrag zur Geschichte der Landfrieden in Deutschland, Könisgsberg, 1879; BERNS, JÜRGEN KARL W., Propter communem utilitatem. Studien zur Bündnispolitik der westfälischen Städte im Spätmittelalter, Düsseldorf 1991; WINTERFELD, LUISE VON, Die Kurrrheinischen Bündnisse bis zum Jahre 1386, Göttingen, 1912; WINTERFELD, LOUISE VON, «Gottesfrieden und deutsche Stadtverfassung», Hansische Geschichtsblätter 23 (1927), pp. 8-56; WINTERFELD, LOUISE VON, «Westfalen in dem großen Rheinischen Bund von 1254», Westfälische Zeitschrift 93 (1937), pp. 128142; PFEIFFER, GERHARD, «Die Bündnis- und Landfriedenspolitik der Territorien zwischen Weser und Rhein im späten Mittelalter», in AUBIN, HERMANN and FRANZ PETRI, Der Raum Westfalen, Munster, 1955, II: pp. 79-140; HENN, VOLKER, «'. . umb Orbar, nutticheit, Raste vnd Vrede onser und anderer stede,' Zur Bundnispolitik der westfälischen Städte im späten 14. und im 15th Jahrhundert», Westfälische Zeitschrift 145 (1995), pp. 9-28; SAATKAMP, FRIEDRICH, Ladbergen. Aus der Geschichte des 1000 jährigen westfälischen Dorfes, 2nd edition, Ladbergen, 1975, pp. 313-315.

11 WERNER, HEINRICH, «Zur Geschichte der Wetterauer Städtebünde im 13. und 14. Jahrhundert», in: Mitteilungen des Oberrheinischen Geschichtsvereins 7 (1898), pp. 56-76.

12 MÄGDEFRAU, WERNER, Der Thüringer Städtebund im Mittelalter, Weimar, 1977; 3rd edition: Thüringen im Mittelalter: Städte und Städebünde, Bad Langensalza, 2010.

13 CZOK, KARL, «Der Oberlausitzer Sechsstädtebund zwischen Bürgergeist, Königsund Adelsherrschaft», in: 650 Jahre Oberlausitzer Sechsstädtebund 1346-1996. Kamenz, 1997, pp. 9-16; DURAND, MANFRED, Die Oberlausitz und der Sechsstädtebund, Waltersdorf, 1991.

14 EPSTEIN, STEPHEN R., «The rise and fall of Italian city-states», in HANSEN, MOGENS HERMAN, A comparative study of thirty city-state cultures: an investigation, Viborg, 2000, pp. 277-294.

15 Bremen, Hamburg, Lübeck, and Erfurt were leaders in this policy: BEHR, HANSJOACHIM, «Die Landgebietspolitik norwestdeutscher Hansestädte», Hansische Geschichtsblätter 94 (1976), pp. 17-37.

16 JOHANEK, PETER, «Imperial and free towns of the Holy Roman Empire: city-states in pre-modern Germany?», in HANSEN, A comparative study of thirty city-state cultures: an investigation, pp. 297-298. 
aristocrats for territorial aggrandizement. ${ }^{17}$ Nevertheless, conflicts with the local nobility and regional princes proved to be a primary impetus for Rhenish urban alliances.

In the same year that the second Lombard League organized against Emperor Frederick II (1226), the urban governments of three Rhenish cathedral cities, Mainz, Worms, Speyer, joined Bingen and the Wetterau imperial cities of Frankfurt am Main, Gelnhausen, and Friedberg to form a seven-city league, the first multilateral urban alliance north of the Alps. This sworn association of mutual aid was directed against the elector-prince, Archbishop Siegfried II of Mainz. The recent depredations of the StaufenWelf dynastic war had weighed heavily on this region, whose territorial sovereignty had been handed to the ecclesiastical elector-princes by Frederick II in 1220 (Confoederatio cum principibus ecclesiasticis) in exchange for their votes for his son Henry (VII) as royal successor. Archbishop Siegfried had been awarded for his abandonment of the Welf cause and coronation of Frederick as king not only in Mainz (1212) but also in Aachen (1215). In the subsequent years, therefore, Siegfried had been busy enforcing his territorial sovereignty over these cities of the middle Rhine, and they finally responded not unlike the Lombard league. ${ }^{18}$

We know next to nothing about this first alliance, as no charters or chronicle accounts survive, though it is striking that it incorporated cities under different territorial lordships. This type of urban collaboration surely displeased the emperor amid his arduous Lombard campaign, and so Frederick II had his son Henry (VII) dutifully announced at a Würzburg Diet (27 November 1226) that all ministerials, dependents, and citizens under the legal jurisdiction of the archbishop of Mainz were to return to him from their refuge in Oppenheim, and the «confederationes sive iuramenta» whereby the seven cities had bound themselves together were to be dissolved. ${ }^{19}$ That

17 EIDEN, HERBERT and FRANZ IRSIGLER, «Environs and hinterland: Cologne and Nuremberg in the later middle ages», in GALLOWAY, JAMES A., Trade, urban hinterlands and market integration c. 1300-1600, London, 2000, 43-57; IRSIGLER, FRANZ, «Stadt und Umland im Spätmittelater: Zur zentralitätsfördernden Kraft von Fernhandel und Exportgewerbe», in MEYNEN, E., Zentralität als Problem der mittelalterlichen Stadtgeschichtsforschung, Cologne and Vienna, 1979, pp. 1-14. Using the criterion of regional economic hegemony, SCOTT, TOM, The city-state in Europe, 1000-1600, Oxford, 2012, p. 230 elects to define Cologne and Augsburg as commercial rather than territorial city-states, "islands of capital without a dependent territory."

18 DILCHER, «Mittelalterliche Stadtkommune, Städtebünde und Staatsbildung. Ein Vergleich Oberitalien-Deutschland», pp. 453-467.

19 RUSER, Die Urkunden und Akten, I, no. 207; WEILAND, LUDWIG, MGH Constitutiones et acta publica imperatorum et regum (1198-1272), Hanover, 1896, reprint 1963, no. 294. 
this imperial ban on regional sworn urban associations was repeated and extended throughout the German kingdom at the Worms Diet (April/May 1231) in the Statutum in favorem principum (in which Frederick II granted territorial sovereignty to the secular princes), and then repeated once again the following year at the Christmas Diet in Ravenna (at the request or the bishop of Worms), indicates that the urban communal movement was as respectful of ultramontane imperial authority as the German princes themselves. This core group of middle Rhine cities in 1226 was only the front edge of the wave.

The imperial ban on multilateral urban leagues led to a period of multiple bilateral friendship treaties for mutual protection, which gradually evolved into a return to multilateral associations by the mid-thirteenth century. Indeed, by 1250 the movement had spread from the middle Rhine to Saxony, Burgundy, and the upper Rhine. ${ }^{20}$ And these regional alliances in turn united during the next round of civil war at the end of the Staufen dynasty, producing what has become known as the Rhenish League (Rheinischer Bund).

Pope Innocent IV's deposition of Frederick II at the Council of Lyon (17 July 1245) released all German princes and nobles from their oaths of loyalty to the emperor, and the last phase of Staufen rule began. Electoral princes of the papal party, the Rhineland archbishops of Cologne, Mainz, and Trier chief among them, elected Landgrave Henry Raspe of Thuringia in 1246 and upon his unexpected death in 1247 Count William of Holland as anti-king to the Staufen imperial heir, Conrad IV. The resulting warfare between the two factions particularly threatened the middle Rhineland cities as the traditional heartland of Staufen power, but was also an opportunity for these cities to advance their own independence through collective, trans-municipal institutions. ${ }^{21}$ So these

20 In 1229 seven cities in the bishopric of Liège formed a mutual aid union; in 1230 Hamburg and Lübeck did the same (renewing the agreement in 1241); in the former Rectorship of Burgundy several Swiss cities began to form alliances from 1239 onward; the first Saxon alliances appear in 1246 and 1252, while the first Westphalian urban alliances appear in 1246 and 1253. BOCK, ERNST, «Landfriedenseinigungen und Städtebünde ab Oberrhein bis zur Gründung des rheinischen Städtebundes von 1381», Zeitschrift für die Geschichte des Oberrheins, Neue Folge 46 (1933), pp. 321-372.

21 The end of Staufen rule was surely the close of the founding era in Rhenish urban history, but it was also the start of a new one in which the foundational institutions of burgher independence and self-rule in each city and town (e.g. communal consciousness, civic associations, city councils and administrative offices) now produced diplomatic and military alliances between their communities. Knut Schulz, «Stadtgemeinde, Rat und Rheinischer Städtebund. Das vorläufige Ergebnis des Prozesses der Kommunalisierung und Urbanisierung um 1250», in FREITAG, WERNER, FRANZ IRSIGLER, PETER JOHANEK, et. al., eds., Bünde - Städte - Gemeinden. Bilanz und Perspektiven der vergleichenden Landes- und Stadtgeschichte [Städteforschung, Darstellungen 77], Cologne, Weimar, Vienna, 2009, pp. 17-39. 
cities actively collaborated in a remarkable project of interregional diplomacy to form a massive self-help organization. It is most remarkable that the Rhenish League would garner such wide support among members that (a) were not all originally loyal to the same king, and (b) were making public sworn oaths expressly forbidden in the repeated bans on sworn urban associations.

In February 1254 the cities of Mainz and Worms were the first to initiate a peace and reconciliation movement by putting aside their recent enmity and renewing their original alliance, ${ }^{22}$ which Oppenheim joined on 4 April and Bingen on 29 May. ${ }^{23}$ Thus territorial peace was established first through bilateral and then multilateral sworn pledges of peace between cities. From this original four-city peace alliance ensued a rapid expansion in membership that is hard to fathom. According to the Worms Chronicle, within two weeks after the death of Conrad IV (21 May 1254) representatives from sixty Rhenish cities met at a great council in Mainz to form a league «according to the example of Worms, Mainz, and Oppenheim» to provide mutual assistance for the next ten years against highwaymen, aristocratic violence, unjust tolls, and taxes, and «because there was no other help or solace available». Together they agreed to set aside all tolls on the Rhine near their cities, even though they held great debt because of the civil war. They further promised to destroy all fortifications of robber barons, and afterward sent emissaries to the following noblemen to invite them to join this association of «holy peace»: the archbishops of Cologne, Mainz, and Trier; the bishops of Worms, Strasbourg, Basel and Metz; eight regional barons, and even more cities. The chronicler concluded, «Although at first unwilling, nevertheless they followed the others, came together at Mainz and swore together on the ten-year peace». ${ }^{24}$ Over the summer and autumn months the city of Cologne also joined this movement along with several other key Rhineland cities from Aachen to Zürich. ${ }^{25}$ The participation of Rhineland princes was critical to the league, not only because of their leadership roles in the civil war but also because of their regalian authority over tolls. The regional barons were also key to stabilizing local violence and robbery so prevalent on the byways of the Rhineland.

22 RUSER, Die Urkunden und Akten, I, no. 172.

23 RUSER, Die Urkunden und Akten, I, nos. 173-174.

24 ZORN, FRIEDRICH, Wormser Chronik, Stuttgart, 1857, pp. 101-102; RUSER, Die Urkunden und Akten, I, p. 201, no. 213; WEILAND, MGH Constitutiones (1198-1272), no. 428/1; ROTH, PAUL, Der Rheinische Bund von 1254, Basel, 1954.

25 Additional cities listed are Neu $\beta$, Wesel, Boppard, Wetzlar, Speyer, Strasbourg, Schlettstadt, Zürich, Freiburg im Breisgau, Breisach, Weissenburg, Neustadt, Wimpfen, Mühlhausen, Gelnhausen. 
The core of this remarkable movement drew from the Peace of God (Gottesfrieden) and Truce of God movements of the eleventh century. ${ }^{26}$ In fact, the collective authors of a letter patent issued to all Christians to announce their 13 July 1254 Mainz agreement -- being listed explicitly as the civic leaders and citizens of Mainz, Worms, Cologne, Speyer, Strasbourg, and Basel -- described their organization as a peace league (Friedensbund). ${ }^{27}$ The letter not only contained the proactive steps taken to rein in violence and injustice, it also delineated specific arrangements for mediators (Schiedsleute) assigned to restore peace and reconciliation should the peace be broken internally by feuds among their members. ${ }^{28}$ These Rhenish burghers acted audaciously when initiating their own interregional peace, because declarations and maintenance of a public peace or truce had been the responsibility and authoritative right of the German monarch since Emperor Henry III issued a blanket peace over the entire kingdom in 1043, which was followed by the imperial peace (Landfriede) established by Emperor Henry IV in 1103 as the First Mainz Imperial Peace. ${ }^{29}$ Though an imperial peace (Landfriede) had already been issued at Mainz in $1235,{ }^{30}$ material conditions and imperial authority had been debased with the collapse of the Staufen dynasty to the point that city officials felt justified as public authorities to initiate resistance against those breaking the peace, «because there was no other help or solace available». ${ }^{31}$ The founding cities of the Rhenish League resided in the heart of Staufen territory, so they experienced most directly the warfare between pro- and anti-Staufen armies, and once Conrad IV died there was no Staufer to restore the hoped-for peace. Thus self-help was the only option at hand. It is typical in German constitutional history to point out the distinction made by territorial princes between the emperor and the empire by the later Middle Ages, yet here too we find Rhenish burghers capable of making this

26 SCHMIEDER, Die mittelalterliche Stadt, p. 137.

27 RUSER, Die Urkunden und Akten, I, no. 209: «Iudices et consules et universi cives Mogonitineses, Colonienses, Wormacienses, Spyrenses, Argentinenses, Basilienses ac alie civitates sancte pacis federe coniurate omnibus Christi fidelibus salutem in eo, qui auctor est pacis et principium salutis.»

28 Each city selected four representatives to a mediation board which would seek to reconcile disputing parties.

29 ARNOLD, BENJAMIN, German knighthood, 1050-1300, Oxford, 1985, p. 16; WATTS, The making of polities: Europe 1300-1500, pp. 101-102.

30 GERNHUBER, JOACHIM, Die Landfriedensbewegung in Deutschland bis zum Mainzer Reichslandfrieden von 1235, Röhrsheid and Bonn, 1952.

31 BUSCHMANN, ARNO, «Der Rheinische Bund von 1254-1257. Landfriede, Städte, Fürsten und Reichsverfassung im 13. Jahrhundert», in HELMUT MAURER, Кommunale Bündnisse Oberitaliens und Oberdeutschlands im Vergleich, Sigmaringen, 1987, pp. $167-212$. 
distinction and acting on behalf of the empire in the absence of an effective emperor.

The Rhenish League moved quickly to recognize William of Holland as the legitimate German king, who in turn provided royal sanction for the league's existence. Cologne was formally taken into the association on 6 October 1254 at the League's Diet in Worms, ${ }^{32}$ though there is internal evidence that Cologne's civic elites worried about expensive entanglements in rather distant disputes. Yet the city's popular enthusiasm for joining this peace movement was given strong voice in the city council, the civic officials (scabini) acceded to this pressure and released a joint public letter with the city council (a rare thing indeed) announcing membership on 14 January $1255 .^{33}$

Diplomacy with William of Holland had resulted in rapid and positive results, and on 6 February 1255 he was formally acknowledged as rightful king at the imperial diet in Worms and in turn he promised his personal protection of the Rhenish League. ${ }^{34}$ The Rhenish League cities had been invited to this imperial diet and thus sent their representatives. The highpoint of the League movement occurred at its own diet in Oppenheim in November 1255, where William of Holland appeared to personally sanction this sworn urban association -- a significant change in imperial policy from previous Staufen decrees. The Rhenish League was from this point an organization with imperially sanctioned legal standing and thus potentially an instrument of imperial policy for the preservation of both

32 The Rhenish League's self confidence in matters moral, political, and religious is quite striking, as we see in the document issued at the Worms Diet: WEINRICH, Lorenz, ed., Quellen zur Verfassungsgeschichte des römisch-deutschen Reiches im Spätmittelalter (1250-1500) [Ausgewählte Quellen zur deutschen Geschichte des Mittelalters 33], Darmstadt, 1983, pp. 14-16: «Ad honorem dei et sancte matris ecclesie necnon sacri imperii, cui nunc preest serenissimus dominus noster Willhelmus Romanorum rex, et ad communem utilitatem equaliter divitibus et pauperibus.» The Rhenish League also made clear in this document the essential purpose of their association: "pro pace servanda».

33 Within a month the archbishops of Mainz and Cologne and the bishops of Worms and Basel made public announcement of their official sworn membership in the Rhenish League, then the judges, lay assessors, and city councilmen of Cologne issued their own public letter (14 January 1255), which also declared their loyalty to William of Holland. The king is mentioned no doubt because Cologne had already joined the Landfriede announced by William at Antwerp: Cologne City Archive, HUA K/196; RUSER, Die Urkunden und Akten, I, p. 206, no. 222 and pp. 206-207, no. 223; WEILAND, MGH Constitutiones (1198-1272), nos. 429-430. See also GROTEN, MANFRED, «Köln und der Rheinische Städtebund 1254», in ROSEN, WOLFGANG and LARS WIRTLER, Quellen zur Geschichte der Stadt Köln, Cologne, 1999, pp. 169-171.

34 RUSER, Die Urkunden und Akten, I, no. 226. 
the imperial constitution as well as of the peace. And what is more, the Rhenish League had become a participant in the shaping of imperial politics. By November of 1255 the noble members of the Rhenish League were joined by many additional princes and barons -- including Countess Adelheid of Leiningen and the abbot of Fulda -- as well as additional cities. ${ }^{35}$ Cologne played a leading role in the Rhenish League, inviting the cities of Westphalia to join with the cities of the Rhineland and the Netherlands and it was soon considered one of the four capital cities of the League along with Mainz, Worms, and Strasbourg. Each year these four cities hosted in turn one the quarterly diets of the League representatives, Cologne's date being the feast day of the Epiphany. ${ }^{36}$ As Cologne's city councilmen took the lead in League affairs, both as document signatories as well as representatives to the quarterly diets, they gained valuable experience in administration and diplomacy apart from the hitherto dominant social group of scabini which had resisted the inclusion of the city council in civic governance. The fact that the city council was now recognized beyond the city walls as a valid and representative organ of Cologne's civic administration was a critical step in establishing the permanence and leadership of the council within Cologne itself. ${ }^{37}$

At its height the Rhenish League had swollen to over sixty cities and more than thirty nobles great and small, including the bishop of Würzburg and the cities of Nuremberg and Regensburg. Surely this peace association had extended well beyond the boundaries of its title, and become a veritable general peace (Landfriede) in much of the German Empire. During the League diets in Mainz (March 1256) ${ }^{38}$ and Würzburg (August 1265), representatives

35 RUSER, Die Urkunden und Akten, I, no. 255; WEILAND, MGH Constitutiones (11981272), no. $428 / 6$.

36 This date (6 January) was appropriate for Cologne, in whose cathedral church lay the relics of the Three Kings (Magi) in a golden reliquary. Of the three other quarterly diets, Mainz hosted on the week after Easter, Worms on 29 June, and Strasbourg on 8 September, all feast days of their respective patron saints. See DISTLER, Städtebünde im deutschen Spätmittelalter, p. 139.

37 GROTEN, MANFRED, Köln im 13. Jahrhundert, Cologne, 1998, pp. 164-166; DISTLER, Städtebünde im deutschen Spätmittelalter, pp. 216-217.

38 The growing self-confidence and sense of purpose among Rhenish League members is reflected in the preamble to the 17 March 1256 charter issued by the Mainz Diet: WEINRICH, Lorenz, ed., Quellen zur Verfassungsgeschichte des römisch-deutschen Reiches im Spätmittelalter (1250-1500) 36: «Universis Christi fidelibus [. . . ] nuncii civitatum congregati Moguncie in colloquio generali salutem et obsequium. Ad laudem et gloriam Jesu Christi, qui est pacis auctor et humane salutis amator, ad honorem eciam sancte Romane ecclesie matris nostre, que pacem et iusticiam amplexatur, pro reverencia quoque imperii, cuius rigore iudicii incorribiles ad viam rectitudinis reducuntur, ad salutem eciam pauperum ac tocius populi christiani.» 
continued to build for a future of peace and conflict resolution: they reached agreements in principle on the banning of usury, feuds, and non-resident citizens (Pfalbürger), the protection of farmers from coercion, taxation, and requisitioning, unified legal procedures for arbitration, regular league assemblies, a tax to fund the League, and even the building of a League navy and assembly hall (a domus pacis, reminding all of the religious mandate to be peacemakers and reconcilers). Though given the membership of princes and nobles in the League it cannot be properly called solely an urban league, nonetheless the majority of the planning, coordinating, and corresponding (both by written documents as well as embassies) were performed by burghers from a remarkably wide array of locations throughout the German Empire.

Yet all this said, only rudimentary changes, such as an end to abusive aristocratic tolls, could be brought to full fruition before the Rhenish League collapsed as suddenly as it had been formed. Just as the League was given life with the death of Conrad IV in May of 1254, so too its own life span was cut short with the sudden death of William of Holland in 28 January 1256. Indeed the 1256 diets at Mainz and Würzburg, which garnered so much diplomatic success, functioned in the shadow of the king's death its portent of future disunity. The burgher members as well as the barons of the League could only hope that the imperial elector princes would prove as unified in electing a new king as they had been in preserving the peace. However, though the princes were present at the Mainz diet in March of 1256, they abandoned them thereafter. The Rhenish League then began to slowly disintegrate throughout 1257 , as members from the lower Rhineland followed their commercial interests in England and joined the electors who chose Richard of Cornwall, while those of the middle and upper Rhineland aligned with the electors who chose Alfonso of Castile. ${ }^{39}$ Initially hesitant to join the Rhenish League, the aristocracy became irritated by the denial of citizenship status (Pfalbürger) in the cities of their territories and even more perturbed by the burghers' efforts to interfere in their rural affairs with the peasantry. The princes and barons never had significant influence within the league, and their stark absence from the diets in 1256 further widened the divide between nobility and cities just as the royal election process degraded into dispute and conflict. At best de iure adjunct partners in the Rhenish

39 HUFFMAN, JOSEPH P., The social politics of medieval diplomacy: Anglo-German relations (1066-1307), Ann Arbor, 2000, pp. 277-300; HUFFMAN, JOSEPH P., «Mitravit me et ego coronabo. The archbishop of Cologne and Richard of Cornwall: an interregional perspective on regnum and sacerdotium», in VAN DEUSEN, NANCY, Medieval Germany: associations and delineations, Ottawa, 2000, pp. 71-92. 
League, the princes and barons could be a stabilizing or a destabilizing force depending upon whether or not a confluence of interests with the burghers remained. The primary interest was a commonly recognized king, like William of Holland, but this confluence flowed into regional associations as another round of weak and distant anti-kings enabled the princes to continue carving out territorial principalities of their own. The Rhenish League had declared at its March and August 1256 diets that no members should acknowledge a royal candidate in the case of a double election, in order to keep the peace (indeed the League was even to impound imperial property and income in such circumstances), and it planned to send representatives to the royal election to plead for a unified decision. For the sake of sustaining their peace movement, the Rhenish League members had even begun to speak on behalf of the empire after the death of its monarch. ${ }^{40}$ Unfortunately for the Rhineland cities this experiment in collaborative interregional diplomacy eroded in the face of aristocratic factionalism. No formal dissolution of the League ever occurred.

Though the Rhenish League did not survive the test of yet another disputed royal election in 1257, primarily because its constituent cities had not yet developed enough independent political and military strength to function on par with the German aristocracy, it was still no small or fleeting matter. This peace association was quickly developing into a powerful polity in the medieval German constitution. In a time of weak monarchy, the League's cities proactively established an increasingly independent institution with both political influence and military success. The Rhenish cities thereby fashioned out of their original regional self-help peace association a centralized authority for preserving the interregional imperial peace (Landfriede), which had traditionally been the preserve of the monarchy. Commercial interests certainly factored in here, but remarkably the Rhenish League focused more on advancing the religious ideals of legal and social justice for the oppressed and of peacemaking through dispute mediation. Furthermore, the League actively pursued these ideals through pragmatic administrative and diplomatic means, indicating that the burgher elites throughout the reach of the League had achieved a new level of self-confidence and administrative expertise.

Abbot Hermann of Niederaltaich acknowledged as much in his assessment of the Rhenish League, «That peace, however, begun in the manner of the

40 WEINRICH, Lorenz, ed., Quellen zur Verfassungsgeschichte des römisch-deutschen Reiches im Spätmittelalter (1250-1500) pp. 40-41. 
Lombard cities, did not last long because of malicious resistance. $»^{41}$ Hermann noticed the Rhenish League's assertion of its own communal authority to organize and function as a peace-keeping institution vacante imperio. Though this interregional league dissolved after 1257 into a heterogeneous collection of regional alliances in the middle and upper Rhineland, in the Wetterau, and in Westphalia based on traditional allegiances and interests, it still continued to serve as the template for regional urban peace associations throughout the remainder of the Middle Ages. ${ }^{42}$ With many more generations of political experience than the burghers, the aristocracy fared no better than the Rhenish League in avoiding a disputed royal election and its consequent warfare. We cannot hold the League accountable for its inability to shape the royal election as it had no such constitutional authority. The outcome of the disputed 1257 elections lay squarely at the feet of the electoral princes and their factions. And though the burghers of the Rhenish League cities found themselves in time divided by the royal election, they had collectively claimed their place in the political culture of thirteenth-century Germany. ${ }^{43}$

\section{THE RHENISH URBAN LEAGUE (RHEINISCHER STÄDTEBUND) 1381-1389}

The Golden Bull issued by Emperor Charles IV in 1356 laid the constitutional foundation for future royal elections by further elevating the seven elector princes (among whom were the Rhenish archbishops of Cologne, Mainz, and Trier) with privileges in exchange for an end to double elections, as four votes of the seven electors now secured a majority-based election. But the Golden Bull also sought to empower the Rhenish elector

41 PERTZ, GEORGE HEINRICH, Hermanni Altahensis Annales, Monumenta Germaniae Historica Scriptores 17, Hanover, 1861, p. 397: "Ista autem pax, more Lombardicarum civitatum incoata, propter maliciam resistencium non diu duravit."

42 From 1257-1381 numerous bi- and multilateral regional alliances formed and reformed in the lower, middle, and upper Rhineland, in Swabia, the Alsace, the Wetterau, Westphalia, Saxony, Thuringia, Upper Lusatia, and Brandenburg, often involving dozens of cities in the multilateral leagues. See for example, SCHILP, THOMAS, «Westfälische Städte und Rheinischer Bund: Überlegungen zur städischen Autonomie in der Mitte des 13. Jahrhunderts», in FREITAG, WERNER, FRANZ IRSIGLER, PETER JOHANEK, et. al., eds., Bünde - Städte - Gemeinden. Bilanz und Perspektiven der vergleichenden Landes- und Stadtgeschichte [Städteforschung, Darstellungen 77], Cologne, Weimar, Vienna, 2009, pp. 41-61.

43 Knut Schulz, «Stadtgemeinde, Rat und Rheinischer Städtebunde», p. 39 concludes enthusiastically, "But let us not impose any inappropriate expectations on the Hansa as well as on the Rhenish Urban League in hindsight, but rather let us admire their achievements and their magnitude for such a short time period from their conception!" (translation mine). Schulz rightly places the Rhenish League on par with the more often recognized Hanseatic League as a signal achievement in medieval European urban history. 
princes further by (once again) banning any «coniurationes, confederationes, et conspirationes» among the cities of the German kingdom, a move designed to weaken cities and their leagues relative to the imperial princes and local barons. A century of regional urban associations sanctioned under King William of Holland's 1255 decree was now challenged by imperial authority. Yet the German monarchs knew the value of cities as a counterbalance to the power of the princes, and Charles IV in particular knew that this decree, itself a tacit admission of the now longstanding and widespread nature of regional urban sworn associations, was problematic in reality. ${ }^{44}$

The Golden Bull, however, did not secure peace in the German kingdom. Only a quarter century after its issuance the deteriorating political conditions in the Rhineland produced a second great interregional urban peace movement. The constant military conflicts between the archbishopric of Mainz and the Count Palatine of the Rhine, coupled with the outbreak of the Great Schism in 1378 and the formation of associations by local barons in southern Germany (Ritterbünde) in 1379, pushed the Rhenish cities beyond their now century-long regional alliances and back to experimenting with an interregional alliance structure. Yet this second great league was not like the first: over the intervening century medieval German cities had grown in their capacity for diplomatic and military organization as well the maintenance of their economic infrastructure. Therefore they proved to be a much more potent political force than in 1254-1257, and went to war this time not so much as a peace association than as a military league.

On 20 March 1381 the cities of Mainz, Worms, Speyer, Frankfurt, Strasbourg, Hagenau and Wissembourg formed an urban alliance to last until Christmas $1384 .{ }^{45}$ This military alliance now known as the Rhenish Urban League (Rheinischer Städtebund) was renewed in 1382 and again in 1392, all the while adding Wetzlar, Friedberg, Gelnhausen, Pfeddersheim, Selz, Oberehnheim, and Schlettstadt. Its organization was more sophisticated than the original Rhenish League, with subdivisions given their own capitals: the middle Rhine at Mainz, the upper Rhine at Strasbourg, and the Wetterau at Frankfurt am Main. Speyer for its part provided the location for the league's regular diets. And each city was assigned specific troop contingents for any given campaign. The league even took a position on the Papal Schism, siding with Pope Urban VI in Rome. ${ }^{46}$

44 GROTEN, Köln im 13. Jahrhundert, p. 240.

45 ENNEN, EDITH, «Rheinischer Städtebund von 1381», in ERLER, A., Handwörterbuch zur deutschen Rechtsgeschichte IV, Berlin, 1990, cols. 1019-1021.

46 RUSER, Die Urkunden und Akten, III, nos. 1-13 for all charters pertaining to the founding diet of March 1381. 
A Swabian Urban League (Schwäbischer Städtebund) of fourteen imperial cities had already formed on 14 July 1376 with Ulm serving as the capital city where delegates met for an annual diet. ${ }^{47}$ A leadership council guided the league between diets, and it quickly joined with the newly reconstituted Rhenish Urban League on 17 June 1381 to form the South German Urban League (Süddeutsche Städtebund). The Swabian Urban League proved to be a thorn in the side of regional nobles, as it continued to expand to 40 cities by 1385 including non-Swabian members such as Nuremberg, Regensburg, Augsburg, Basel, and Mühlhausen. ${ }^{48}$ Though the two leagues would remain separate entities they combined their diplomatic and military strategies to become a major force in German imperial history in the 1380s, even extending their diplomatic reach to an affiliation with the emerging Swiss Confederation on 21 February 1385. During their first two years as a joint coalition the South German Urban League enjoyed decisive military victories against the baron leagues of St. George, St. William, and the Lion's League (Löwenbund or Löwengesellschaft). ${ }^{49}$ Indeed the league members felt themselves collectively secure enough by March 1383 to ignore the Nuremberg Landfriede negotiated King Wenceslaus, such that the peace association that emerged from Nuremberg became scornfully known as the «Nuremberg Lord's League» (Herrenbund).

King Wenceslaus finally achieved an uneasy truce between the warring parties in Heidelberg on 26 July 1384 (Heidelberger Stallung), yet Rhenish Urban League members did not participate in the truce's renewal in Bad Mergentheim (Mergentheimer Stallung) on 5 November 1387. Warfare was fatefully renewed when Archbishop Pilgrim II of Salzburg joined the Swabian Urban League against Duke Frederick of Swabia, unleashing the First South German War of Cities (Städtekreig), into which the Rhenish Urban League members were drawn. The Swabian league was decimated by Count Eberhard II of Württemberg at the Battle of Döffingen (24 August 1388), and its cities were gradually occupied and then subjected

47 Founding cities were Ulm, Konstanz, Überlingen, Ravensburg, Lindau, St. Gall, Wangen, Buchhorn, Reutlingen, Rottweil, Memmingen, Biberach, Isny, and Leutkirch. RUSER, Die Urkunden und Akten, II, no. 596.

48 RUSER, Die Urkunden und Akten, II, no. 671; VISCHER, WILHELM, «Geschichte des schwäbischen Städtebundes der Jahre 1376-1389» Forschungen zur deutschen Geschichte 3 (1863), pp. 194-202.

49 ZILKE, SONJA, «Die Löwen-Gesellschaft, ein Adelsbund des 14. Jahrhunderts», Zeitschrift zur Geschichte des Oberrheins 138 (1990), pp. 27-97. The Lion's League was led by the counts of Nassau, Katzenelnbogen, and Wied and had a large membership of barons and knights who made the trade routes of the middle and upper Rhine very treacherous for merchants and diplomats to travel. 
to the Landfriede decreed by Wenceslaus at Eger/Cheb (5 March 1389), complete with yet again another decree banning urban sworn alliances. The Rhenish Urban League was likewise decisively defeated near Worms at Pfeddersheim on 6 November 1388 by Count Palatine Ruprecht II and followed the others into the Landfriede of 1389. In return for their entrance into the imperial peace, Wenceslaus was careful to confirm to the cities of both leagues their traditional liberties as imperial and free cities. ${ }^{50}$ The great urban leagues of the 1380s were broken for the time being, as their huge debts, enforced war reparation payments, and diminution of their military capacities resulted in a return into their respective regional contexts in order to recover. Yet by 1390 a second Swabian Urban League was formed that would continue throughout the fifteenth century, never again however reaching the size of the $1380 \mathrm{~s} .{ }^{51}$ Only a concerted and massive military response by king, princes, and barons succeeded in dismantling these two powerful urban leagues. The Rhenish cities and their Swabian allies had made clear what capacities these German cities had developed for collaborative military intervention. Rhenish cities were no longer only economic forces on an aristocratic landscape, they were political and military powers whose significance could never again be underestimated. The level of administrative, diplomatic, and military coordination alone required in the 1380s rivals any medieval aristocratic or imperial campaign, and though such interregional leagues ceased to form, the lessons learned here were applied in the many continuing regional urban leagues in Alsatia, Swabia, Saxony, and other parts of the German empire, not to mention the most notable heir to the interregional league tradition: the Swiss Confederation (Eidgenossenschaft), whose existence the Luxembourg emperor Charles IV had intentionally excluded from the Golden Bull as this suited his antiHapsburg politics.

50 ENNEN, «Rheinischer Städtebund von 1381», cols. 1019-1021. This particular era of regional war put serious pressure on the inner cohesion of the Swabian Urban League, which was often expressed by the resistance of individual cities to the central authority of the League's permanent council in Ulm: Stefanie Rüther, «Der Krieg als Grenzfall städtischer "Außenpolitik"? Zur Institutionalisierung von Kommunikationsprozessen im Schwabischen Städtebund (1374-1390)», in JORG, CHRISTIAN and JUCKER, MICHAEL, eds., Spezialisierung und Professionalisierung: Träger und Foren städtischer Aussenpolitik während des späten Mittelalters und der frühen Neuzeit [Trierer Beitrage zu den Historischen Kulturwissenschaften 1], Trier, 2010, pp. 105-120.

51 BLEZINGER, HARRO, Der Schwäbische Städtebund in den Jahren 1438-1445. Mit einem Überblick über seine Entwicklung seit 1389, Stuttgart, 1954. 


\section{BETWEEN THE RHENISH LEAGUES: COLOGNE AND REGIONAL URBAN LEAGUES}

Now that we have considered at the macro level the evolution of the two great interregional urban leagues involving the Rhineland, let us take a close look at a regional league on a micro level for more specifics on their origins, structures, and outcomes. The two great interregional leagues (Rhenish League, Rhenish Urban League) serve as bookends to the many and varied regional urban leagues that developed in the century between them. Indeed, the regional urban leagues actually outnumbered and outlived the two great interregional urban leagues, and so deserve consideration here. We shall look to the Rhenish metropolis of Cologne for our example.

Cologne had been establishing bilateral urban alliances since 1149 when it secured a treaty with Trier, ${ }^{52}$ and among the few surviving charters of such agreements there remains a 4 November 1252 charter with Boppard in which a protocol for resolving unpaid debts between their citizens was articulated in order to limit arrests and litigation before their respective courts. ${ }^{53}$ Such mutual legal protections were a common early form of collaboration between Rhineland cities, as were mutual citizenship status between cities. ${ }^{54}$ After driving out the archbishop of Cologne from his cathedral city in 1288 the citizens of Cologne needed such regional urban alliances more than ever to sustain their autonomy as a free city. Yet such alliances were complicated, since other regional cities were still under the lordship of the archbishop of Cologne. When Andernach, Bonn, and Koblenz established an urban alliance in February 1301 «to avoid conflicts with their neighbors», all three cities were still careful to delimit their oaths by reserving the rights of their lord the archbishop of Cologne. ${ }^{55}$ Now these three cities were preparing for conflict with their lord the archbishop regarding the exactions at their tolls, and yet they were still scrupulous in recognizing that he had legitimate regalian rights over those tolls.

Only with royal sanction then was Cologne able to ally itself legally with other regional cities against the interests of the archbishop. Such an

52 HIRSCHMANN, Die Stade im Mittelalter, p. 38.

53 Cologne City Archive, HUA 181; ENNEN, LEONARD, Quellen zur Geschichte der Stadt Köln II, Cologne, 1863, no. 310; RUSER, Die Urkunden und Akten, I, no. 191.

54 RUSER, Die Urkunden und Akten, I, no. 396: Tilmann of Cologne appears among the signatories of the 9 May 1285 alliance between Frankfurt am Main, Wetzlar, and Friedberg. He was a citizen of Frankfurt am Main, who also appears as a signatory on the 1 December 1285 reissue of the alliance which then included Gelnhausen (RUSER, I: no. 398).

55 RUSER, Die Urkunden und Akten, I, nos. 196-197; II, no. 3. 
opportunity arose over these very tolls in May of 1301, when the Hapsburg king Albert I empowered the cities of Cologne, Koblenz, Andernach, Bonn, Neu $\beta$, Bacherach, Lahnstein, Rheinberg, Schmithausen, Mainz, Trier, Worms, Speyer, Strasbourg, Basel, and Constance «to establish and swear to a general peace» against the unjust tolls, levies, and convoy fees forced on them by the elector-prince archbishops of Cologne, Mainz, and Trier. ${ }^{56}$ Not only did the king authorize the formation of an urban league against the three Rhenish prince-archbishops, he ordered the league «to actively resist with impunity the collectors of the tolls and convoy fees» along the Rhine until such exactions were returned to their levels in Emperor Frederick II's reign. The Rhenish cities were a critical ally for the king in his struggle with these prince-archbishops arrayed against him.

The conflict over abuses in tolls and fees went favorably for Albert I until his assassination on 1 May 1308, and then dragged on into the reign of the Wittelsbach king Ludwig IV, whose disputed royal election in October 1313 had drawn the archbishops of Mainz and Trier as well as King John of Bohemia as elector-princes to his side. With their aid he announced on 22 June 1317 a final settlement of the issue through another Landfriede involving the archbishops of Mainz and Trier, King John of Bohemia, various nobles, and the citizens of Cologne, Mainz, Worms, Speyer, Aachen, Oppenheim, Frankfurt, Friedberg, Gelnhausen, and Wetzlar. ${ }^{57}$ All tolls beyond traditional convoy fees were abandoned by the archbishops of Mainz and Trier, and all new tolls from Cologne to Antwerp were also outlawed. Archbishop Henry II of Cologne, however, as a partisan elector of King Ludwig's Hapsburg cousin and anti-king Frederick «the Fair» of Austria, had not entered into this peace agreement. But Ludwig stipulated that should he choose to join he could retain a portion of his traditional regalian toll income within his principality during the term of the Landfriede (i.e. six of the twenty-two gros Tournois ${ }^{58}$ per cartload of wine, with the remaining sixteen going to the king) but if not this income would be cut off as an inducement to joining the peace. The Landfriede remained in force for seven years, during which

56 Cologne City Archive, HUA 671; RUSER, Die Urkunden und Akten, I, no. 286; SCHWALM, JACOB, MGH Constitutiones et acta publica imperatorum et regum (12981313), Hanover, 1906, reprint 1981, no. 134.

57 Cologne City Archive, HUA 878-879; SCHWALM, JACOB, Constitutiones et acta publica imperatorum et regum (1313-1324), Hanover, 1909, reprint 1981, no. 421.

58 The gros Tournois, or Tours Groschen, was one of the first French «great coins» or thick silver coins, valued at about 10-12 pennies (denarii) and thus roughly comparable to a shilling (solidus): SPUFFORD, PETER, Money and its use in medieval Europe, Cambridge, 1988, p. 299. Archbishop Henry II of Cologne had Grosspfennig coins minted in Bonn. 
time no toll rates could be raised. The citizens of Cologne were also given instructions to «help with at least four people [as representatives to the alliance], as had been agreed upon in their previous alliance with the lords of 5 June 1288» This reference to the earlier Battle of Worringen, where a coalition of regional counts and nobles had joined Cologne to rout the archbishop of Cologne's army, was a powerful allusion for Archbishop Henry II, because he himself had fought as a youth in the Battle of Worringen alongside his father Count Henry II of Virneburg and brother Ruprecht -- ironically for the Cologne coalition against Siegfried of Westerburg, then archbishop of Cologne. On the next day, the king along with the archbishops of Mainz and Trier and the king of Bohemia (pro-Wittelsbach elector-princes all) clarified the stipulations concerning regalian toll incomes: of twentytwo gros Tournois, the king's share should be garnered thus: seven should be raised at the Koblenz toll, and nine at the Remagen toll. If the archbishop of Cologne upheld the peace he should receive the remaining six, three from the Andernach toll and three from the Bonn toll. But if the archbishop refused, then the king would receive only three from Koblenz and three from Remagen, with the remaining sixteen placed into the Landfriede war fund against the archbishop. ${ }^{59}$

The city councilmen of Cologne went straight to work implementing these stipulations, as a letter to them from their counterparts in Speyer makes clear. ${ }^{60}$ The latter informed them that they had sent their citizen, Henry of Regensburg, to Cologne as the toll supervisor, to whom the Cologners should give a key for the money chest. The Speyer councilmen assured them that Henry had already taken an oath to them and to the officials of Mainz and Worms as well to collect the toll justly. In return, the Cologne councilmen were admonished to take the same oath before their own city council as well before the representatives of Mainz, Worms, and Speyer. This letter suggests a well-organized, collaborative financial, diplomatic, and communication system emerging in support of the Landfriede league, complete with funding for the peace-keeping effort and documented communication between urban chanceries.

Under such mounting pressure, on 9 July 1317 Archbishop Henry II of Cologne came half way into the Landfriede, opting to join but reserving the rights of (and thus his loyalty to) King Frederick. ${ }^{61}$ Archbishop Henry II had in fact not only cast his electoral vote for Frederick, but also crowned

59 RUSER, Die Urkunden und Akten, I, no. 289.

60 RUSER, Die Urkunden und Akten, I, no. 291.

61 SCHWALM, MGH Constitutiones et acta publica imperatorum et regum (1313-1324), Hanover, 1909, reprint 1981, no. 435. 
him in the Bonn Minster on 25 November 1314. Thus preparations for war with the archbishop of Cologne continued apace. Surviving correspondence indicates that Cologne, Mainz, Worms, and Speyer did indeed elect four officials each with a treasury chest key to coordinate the war finances of the league, and the chest was only to be opened with the permission of all the financial magistrates of each city. ${ }^{62}$ All parties were kept apprized concerning any changes to the status of the elected financial magistrates through letters patent, as when Speyer notified the masters, councilmen and citizens of Cologne that Henry of Regensburg had fallen ill in October 1317 and Hermann of Brussels (another Speyer citizen) had been deputized in his place as toll collector, ${ }^{63}$ and then two months later that their citizen Fritz had now been deputized «to collect the wages for the soldiers from the toll funds at Cologne, according to the treaty with the city of Bacharach». ${ }^{64}$

Archbishop Henry II of Cologne also received countervailing pressure from his chosen monarch to respond with force against the Landfriede in the Rhineland. On 10 February 1318 Frederick issued a letter to Henry II, telling him that the king had just received word while in Austria that «certain communities of quite a few cities on the Rhine made a reprehensible alliance» and with a false pretense of upholding a Landfriede they deceitfully established new tolls at Cologne, Koblenz, and Remagen, even making the clergy pay and asking everyone to pay more than was formerly done. Frederick then castigated the archbishop for agreeing to abandon his tolls at Andernach and Bonn and entering into the seven-year peace himself. Therefore the king ordered the archbishop to restore his tolls and with the support of his vassals to «punish all those with high treason who rebel against this». Though Frederick made clear that he was unable to intervene himself, he authorized the archbishop to fight to maintain the king's regalian prerogatives in the Rhineland. ${ }^{65}$ Henry II was now in an untenable position: he either defied his monarch as a traitor or became a breaker of the peace which he had sworn to uphold, both of which were equally felonious offenses.

62 Cologne City Archive, HUA 894 dated 1 August 1317; RUSER, Die Urkunden und Akten, I, no. 292; SCHWALM, MGH Constitutiones (1313-1324), no. 438. In this letter the civic leaders and citizens of Mainz swear that they would protect securely the toll funds gathered at Koblenz and for that purpose elected four men from their city council each with a key for the money chest, which they should only open with the other cities' collective approval, "and only for the benefit of the general peace."

63 Cologne City Archive, HUA 901 dated 19 October 1317; SCHWALM, MGH Constitutiones (1313-1324), no. 463.

64 RUSER, Die Urkunden und Akten, I, no. 294.

65 RUSER, Die Urkunden und Akten, I, no. 295; SCHWALM, MGH Constitutiones (13131324), no. 472. 
The archbishop chose to support his king, and thus proceedings began against the him as a peace breaker at an alliance meeting in Oppenheim on 2 April 1318, at which the Cologne citizen John of Bayen made the case for action on behalf of Archbishop Baldwin of Trier, Count Gerhard of Jülich, and the city council of Cologne before representatives of Mainz, Worms, Speyer, Oppenheim, Frankfurt, Wetzlar, Friedberg, and Gelnhausen. After exhorting all parties to hold to the founding Landfriede charter of Bacherach, the Cologne-Jülich-Trier group formally charged the archbishop of Cologne with raising illegal tolls, robbing, and even imprisoning merchants. In particular the archbishop of Trier declared that, losing 20,000 pounds of pennies per annum from tolls to the peace fund, he would deny any further funding from the toll of Koblenz should the remaining cities chose not to go to war. Furthermore, the Cologne city council openly declared its readiness to take the field of battle, with John of Bayen promising that complaints from some cities about the Cologne representatives use of toll funds (no doubt to prepare for war) without their permission would be duly addressed at the next meeting of alliance representatives.

Finally, the audience was assured that Count William of Hainault, (the alliance's chosen Landfriede military chief), Count Gerhard of Jülich, and the city of Cologne had repeatedly admonished the archbishop of Cologne to uphold the peace yet received no response from him. Thus the time had come to issue the final warning to the archbishop since the season for campaigning was upon them all. ${ }^{66}$ Clearly the city council of Cologne took the lead in persuading the alliance cities to move militarily against the archbishop of Cologne, as they were feeling the pressure of his peace-breaking actions more than their allies. A targeted and limited military response was quickly approved, as on 4 May 1318 Count William of Hainault issued a letter confirming that the citizens of Cologne had, at the command of his own brother John, besieged the archbishop of Cologne's town and castle at Brühl, from whence the Landfriede had often been broken. ${ }^{67}$

The Cologne-Jülich-Sponheim-Hainault coalition army quickly captured Brühl, and given the presence of Cologne patricians Gerhard Overstolz, Gottschalk Overstolz, and Gotthart Hardevust as signatories on the subsequent formal letter of cause (Anlassbrief) against Archbishop Henry II, the traditional social elites of Cologne had closed ranks with the city councilmen of the

66 Cologne City Archive, HUA 922; RUSER, Die Urkunden und Akten, I, no. 296; SCHWALM, MGH Constitutiones (1313-1324), nos. 488-489.

67 Cologne City Archive, HUA 924; RUSER, Die Urkunden und Akten, I, no. 297; SCHWALM, MGH Constitutiones (1313-1324), no. 490. 
parishes. The Overstolz and Hardevust scabini issued this formal letter on 17 June 1318 along with Count John of Sponheim and vassals of Count Gerhard of Jülich on behalf of Cologne, the count of Jülich, and their Landfriede allies (Eidgenossen) to Archbishop Peter of Mainz, Archbishop Baldwin of Trier, and Grand Master Karl of the Teutonic Knights, calling on these recipients to pass judgment on the charges against the archbishop of Cologne before Christmas eve of 1318, to force the archbishop of Cologne to uphold the peace, and to take possession of the town and castle of Brühl as surety until they should render judgment. Thus the formal process for mediation was begun as the two archbishops and grand master officially confirmed their acceptance of the role of mediators (Schiedsleute) in the case before them. ${ }^{68}$ Their swift reply on the same day only declared that clergy belonging to the city of Cologne and thus under the Landfriede should retain their freedoms and incomes. Yet they refused to adjudicate the charges of peace-breaking by the archbishop. ${ }^{69}$

While settling ecclesiastical matters, this decision hardly provided a means to resolve the outstanding moral and political grievances. So an appeal drew out the case to the deadline of Christmas eve of $1318,{ }^{70}$ at which the mediators rendered a fuller decision. ${ }^{71}$ All supporters of the archbishop imprisoned in Brühl castle were to be released, all clerics reinstated to their status before the war and any alliances they joined were to be abandoned; the archbishop and his allies were to uphold the Landfriede according to its charters and give back all seized goods; both parties were to confirm in writing their willingness to let the archbishop of Trier hold the town and castle of Brühl until the case was finally settled, and the archbishop was to have his cities of Bonn, Andernach, and Neu $\beta$ confirm in writing that they would not assist him in future should he fail to hold to this decision. The mediators still refused, however, to adjudicate cases regarding either plunder and arson committed in open battle or the sensitive issue of the Rhine tolls. The matter of tolls proved very difficult to resolve as royal

68 Cologne City Archive, HUA 926-927; RUSER, Die Urkunden und Akten, I, no. 298; SCHWALM, MGH Constitutiones (1313-1324), no. 491.

69 Cologne City Archive, HUA 929; RUSER, Die Urkunden und Akten, I, no. 299; SCHWALM, MGH Constitutiones (1313-1324), no. 492.

70 On 19 June 1318 Count William of Hainault wrote to inform the allies (the magistrates of Cologne primary among them) concerning their league's «holy peace» that he had to resign the office of Landfriede military chief, given the burden of wars closer to home. He continued, however, to uphold the peace as an ally: Cologne City Archive, HUA 930; RUSER, Die Urkunden und Akten, I, no. 31; SCHWALM, MGH Constitutiones (1313-1324), no. 494.

71 Cologne City Archive, HUA 949; RUSER, Die Urkunden und Akten, I, no. 302; SCHWALM, MGH Constitutiones (1313-1324), no. 519. 
regalia rights were claimed by rival kings (the Wittelsbach Ludwig IV and the Hapsburg Frederick of Austria). Thus the key element in any mediated reconciliation of feuding parties, reparations for damages, went unaddressed by this tribunal. It would take another twenty months of further negotiations with new mediators to reconcile these outstanding issues.

For this purpose both Archbishop Henry II and the Cologne city officials agreed on Count Gerhard of Jülich (who proved an able arbitrator despite his participation in the capture of Brühl) and John of Kuik, the provost of St. Servatius in Maastricht, as the mediators. In a decision acceptable to both sides was announced on 15 August $1320^{72}$ by the count. John of Kuik had arranged for an ecclesiastical court of arbitration under Emico of Sponheim (a member of the Cologne cathedral chapter) to settle within three months all matters affecting prelates and clerics either appointed to offices in Cologne or who left the city in support of the archbishop during the war, with the cathedral provost settling any appeals that could not be reconciled by then. The count of Jülich reconciled the archbishop with the citizens of Cologne, whereby all prisoners were freed and the sticky issue of tolls was resolved. The archbishop was allowed to collect fourteen gros Tournois for each cartload of wine, but only at the tolls of Bonn and Andernach, from which he would pay three from the Bonn toll and one from Andernach until all his reparation debts to Cologne citizens were paid in full. He also abandoned all other illegal tolls and transit fees and agreed to uphold the peace until its expiration on 24 June 1324, issuing letters patent to this effect and ordering his own brother Ruprecht of Virneburg, the provosts of Bonn, Tomberg, Kerpen, and Theonburg, and all his magistrates to do likewise. A protocol was also established to adjudicate any future conflicts between city and archbishop: if a merchant or someone else passing through the archbishop's land were robbed, imprisoned, wounded, or killed the aggrieved party or the citizens of Cologne (on his/her behalf) should complain directly to the archbishop, who or whose magistrates must judge the case and indemnify within four weeks. If the archbishop was not in the land, the case should be brought to the burgrave of Brühl. Should any magistrate refuse to cooperate he was to be deposed as a perjurer and his own goods were seized to indemnify the aggrieved party. Quite remarkably, to assure that the archbishop and his magistrates observed this agreement, the castle and town of Brühl was given to the city of Cologne as security for the remainder of the Landfriede and assigned to the knight Kuno of

72 Cologne City Archive, Urkunden Kopiar 1, folio 75; LACOMBLET, THEODOR JOSEPH, Urkundenbuch für die Geschichte des Niederrheins, III, Düsseldorf, 1853, no. 180. 
Vieschenich as burgrave, who would remain in office until all outstanding claims were settled, even if this went past the 27 June 1324 expiration date of the Landfriede. ${ }^{73}$ Should archbishop or his magistrates again break the peace, the burgrave would open the castle and town to the citizens of Cologne. Finally, the irreconcilable issue of divided allegiances to monarchs was handled deftly. The archbishop of Cologne was allowed to «serve and help the Duke of Austria, whom he recognizes as king», while the count of Jülich and the citizens of Cologne served and helped «their lord, King Ludwig,» with both sides allowed to contribute funds to their respective lords as service. Most importantly, this clause was added to maintain the regional peace: «If these lords come into the land, everyone on both sides should defend themselves and not enter into war against or damage each other». Finally, the delicate equilibrium existing before the outbreak of hostilities was reinstated: the regalia rights of courts, lordship, and properties were confirmed to the archbishop, while the citizens of Cologne were promised the right to «remain in their peace and customs». The final admonition brought the peace-making process to a close: «Both parties should be completely reconciled».

This peace held for a time, as evidenced by Archbishop Henry II's presence in the city of Cologne to consecrate the new cathedral's high choir on 27 September 1322. But in 1359 another Cologne-led regional urban alliance formed, this time including Bonn, Andernach, Koblenz, to forcibly prevent a later archbishop of Cologne (William of Gennep) from building a new fortress at Rolandswerth (just south of Bonn) in order to dominate the middle Rhine valley. ${ }^{74}$ Cologne promised a contingent of 2,500-3,000 armed soldiers and 100 archers delivered by ship to destroy the new castle, leading the archbishop to abandon the venture. The net result was the formation of a ten-year «union and friendship» league founded on 7 September 1359 by Cologne, Bonn, Koblenz, Andernach, and Oberwesel, which secured not only a military alliance against the archbishop of Cologne, but also established protocols for legal equality and justice, the banning of debt imprisonment, provision of mutual aid and conflict arbitration for all the citizens of these cities, alongside a collective diplomatic policy toward those outside of the league. As evidence of the remarkable level of collective allegiance and collaboration achieved by urban leagues of the mid-fourteenth century, this regional Rhenish league appointed four jurors from each city to handle its affairs, all of whom swore «to uphold all the pertaining articles in this letter

73 ENNEN, LEONARD, Quellen zur Geschichte der Stadt Köln, IV, Cologne, 1870, no. 89.

74 Cologne City Archive, HUA 2256-2257; RUSER, Die Urkunden und Akten, II, nos. 519520; ENNEN, Quellen zur Geschichte der Stadt Köln, IV, nos. 404-405. 
[of alliance] and also not to depart from them in mortal danger and even when matters go against their city, relatives, or friends». ${ }^{75}$ By this point in time the Rhenish cities had developed a very sophisticated network of welltrained emissaries and messengers who maintained close communication between them, and this in turn cultivated a maturing diplomatic culture and information systems that rivaled anything seen at royal and aristocratic courts. ${ }^{76}$ And though they were never fixed entities but rather ever evolving amalgamations of a myriad of different sorts of urban communities, they still provided an trans-urban venue for experimenting with collective selfgovernment and self-help. ${ }^{77}$

Medieval bourgeois aspirations for urban autonomy did not stop at the city walls, and civic life existed between these walls as well as within them. The Rhenish urban leagues, both regional and interregional, reveal a significant scope and sophistication of administrative, diplomatic, communication, financial, and military integration that reach well beyond traditional historiographies on trade routes and commercial development. Indeed, these mutual self-help alliances contributed to medieval political culture by enabling the development of a distinctive inter-urban diplomatic culture, which inculcated in their bourgeois leaders the practice of thinking beyond their own city's private interests and toward the collective good of a much larger regional or interregional community -- indeed, sometimes even of the Empire as a whole. Rhenish urban alliances therefore ought to be included with town councils, executive officers, and municipal constitutions in any account of European political culture, constitutional development, territorial government, and conflict resolution during the central and later Middle Ages.

75 Cologne City Archive, HUA 2263-2264; RUSER, Die Urkunden und Akten, II, pp. 530-533, nos. 521-522; ENNEN, Quellen zur Geschichte der Stadt Köln, IV, no. 409; LACOMBLET, Urkundenbuch für die Geschichte des Niederrheins, III, no. 595.

76 The greatest challenge in this emerging urban diplomatic culture was the varying degrees of authority given by cities to their emissaries, which often made for difficulties and delays in decision-making: KREUTZ, BERNHARD, «Botenwesen und Kommunikation zwischen den mittelrheinischen Kathedralstädten von 1254 bis 1384», in JORG, CHRISTIAN and JUCKER, MICHAEL, eds., Spezialisierung und Professionalisierung: Träger und Foren städtischer Aussenpolitik während des späten Mittelalters und der frühen Neuzeit, pp. 95-104.

77 KEELING, REGULA SCHMID, "Vorbehalt" und "Hilfskreis." Grenzsetzungen in kommunalen Bündnissen des Spätmittelaters», in HITZBLECK, KERSTIN and KLARA HÜBNER, eds., Grenzen der Netzwerke 1200-1600, Ostfildern, 2014, pp. 175195 emphasizes the careful ways that individual cities hedged their obligations to their league with various caveats and careful circumscribing of just what help they owed to the league. Yet she also concludes that they were indeed networks in which urban self-interests were amalgamated through diplomacy into collective self-help. 